\title{
PENGARUH PENAMBAHAN TEPUNG CANGKANG TELUR TERHADAP KARAKTERISTIK MIE BASAH YANG DIHASILKAN
}

\author{
Tria Asviani $^{(1)}$, dan Retti Ninsix, S.Tp., MP ${ }^{(2)}$ \\ ${ }^{(1)}$ Alumni Teknologi Pangan Faperta UNISI \\ ${ }^{(2)}$ Dosen Teknologi Pangan Faperta UNISI
}

\begin{abstract}
Abstrak
Penelitian ini bertujuan untuk persentase tepung cangkang telur yang tepat pada pengolahan mie basah terhadap karakteristik mie basah yang dihasilkan sesuai dengan syarat mutu mie basah menurut SNI 2046-90. Penelitian ini mengolah cangkang telur menjadi tepung lalu selanjutnya diolah kembali menjadi mie basah untuk memanfaatkan cangkang telur yang hanya menjadi limbah dimasyarakat, karena cangkang telur memiliki kandungan kalsium yang cukup tinggi untuk memenuhi kebutuhan tubuh manusia.

Rancangan percobaan pada penelitian ini menggunakan Rancangan Acak Lengkap (RAL) dengan 4 perlakuan yaitu perlakuan A (Tepung Cangkang Telur $7,5 \%$ per Berat Bahan), B (Tepung Cangkang Telur $15 \%$ per Berat Bahan), C (Tepung Cangkang Telur 22,5\% per Berat Bahan), D (Tepung Cangkang Telur 30\% per Berat Bahan), dengan berat bahan 250 gram tepung terigu. Analisa yang dilakukan untuk mengetahui pengaruh penambahan tepung cangkang telur terhadap karakteristik mie basah yang dihasilkan diantaranya yaitu kadar kalsium, kadar air, kadar abu dan organoleptik (Rasa, Warna, Aroma, dan Tekstur). Hasil karakteristik mie basah terbaik dari penelitian ini yaitu pada perlakuan A dengan penambahan tepung cangkang telur $7,5 \%$ per berat bahan yang menghasilkan nilai kadar kalsium $0,32 \%$, nilai kadar air $19,33 \%$, nilai kadar abu $1,30 \%$, nilai rasa 3,70, nilai warna 4,50, nilai aroma 3,40 dan nilai tekstur 3,50.
\end{abstract}

\section{Kata Kunci : Tepung Cangkang Telur, Karakteristik Mie Basah}

\section{PENDAHULUAN}

Telur ayam merupakan bahan makanan yang banyak dikonsumsi oleh lapisan masyarakat, karena nutrisinya yang tinggi, sebagai sumber protein,dan harganya yang terjangkau. Selain itu telur ayam juga banyak dijadikan bahan baku olahan yaitu roti, kue, mie, kosmetik dan lain-lain.

Telur ayam yang telah dimanfaatkan untuk pengolahan atau bahan makanan biasanya menghasilkan limbah yang disebut dengan cangkang atau kulit yang tentu sudah tidak terpakai lagi dan masyarakat pada umumnya membuangnya sebagai limbah tanpa memanfaatkannya terlebih dahulu. Di Indonesia produksi limbah cangkang telur ayam akan terus meningkat selama telur ayam diproduksi dibidang peternakan serta digunakan dirumah makan, restorant, pabrik roti, dan mie sebagai bahan baku pembuatan makanan. Menurut data Direktorat Jendral peternakan (2009) produksi telur di Indonesia tahun 2009 sebesar 1.013.543 ton (Wulansari dkk 2013) dan meningkat pada tahun 2012 sebesar 
1.059.266 ton (BPS 2012 dalam Mairizon 2013). Telur terdiri dari 3 komponen pokok yaitu, kulit telur atau cangkang(11\% dari bobot tubuh), putih telur (57\% dari bobot tubuh), kuning telur (32\% dari bobot tubuh) (Sudaryani 2006 dalam Mairizon 2013). Porsi cangkang telur pada satu butir telur adalah $11 \%$, maka diperkirakan limbah cangkang telur pada tahun 2012 adalah sebesar 10.592.66 ton (Mairizon 2013).

Cangkang telur ayam ras mengandung kalsium dan mineral seimbang, tersusun atas senyawa protein sederhana yang berupa albumin dan memiliki struktur yang kuat. Didalam cangkang telur terkandung logam mineral organik yang berupa $\mathrm{Ca}$. Kulit telur kering terdiri atas $95 \%$ kalsium karbonat dengan berat 5,5 gram. Cangkang telur ayam ras terdiri atas 97\% kalsium karbonat. Selain itu rerata dari cangkang telur mengandung 3\% fosfor dan 3\% terdiri atas magnesium, natrium, kalium, seng, mangan, besi, dan tembaga (Wulansari dkk 2013).

Kalsium memiliki dua fungsi penting yaitu pembentukan tulang dan gigi. Kebutuhan kasium terbesar adalah selama masa anak-anak, akan tetapi kebutuhan kalsium akan berlanjut hingga masa dewasa. Ketika tulang terbentuk, tulang baru akan terbentuk juga secara berkelanjutan dan tulang lama akan dirombak. Pembentukan awal tulang yang tidak sempurna akan memicu terjadinya osteoporosis dimasa tua, oleh karena itu pembentukan tulang harus dijaga sejak dini dengan pemberian kalsium yang cukup pada anak-anak. Pada survei nasional menunjukan asupan kalsium pada masyarakat Indonesia masih kurang. Pemeriksa DMT (Densitas Mineral Tulang) yang dilakukan PT.New Zealand Milk terhadap 17.000 penduduk di 14 kota besar Indonesia menunjukan bahwa jumlah penderita osteoporosis usia produktif (25-34 tahun) sebanyak $\pm 6 \%$ (kompas 2007 dalam Lesmana dkk, 2008). Hal ini menunjukan masyarakat Indonesia masih membutuhkan asupan kalsium sebagai salah atau komponen gizi yang dapat membantu mencegah timbulnya osteoporosis yang dapat diupayakan sejak dini yaitu mulai masa anak-anak. Untuk itu perlu dicari alternatif peningkatan kalsium yang salah satunya memanfaatkan cangkang telur ayam menjadi produk.

Penelitian (Rahmawati, 2014) yang menggunakan tepung cangkang telur sebagai fortifikasi pada proses pengolahan cookies untuk menambah jumlah kalsium pada cookies. Penambahan tepung cangkang telur tersebut menghasilkan respon yang baik terhadap karakteristik cookies. Dimana penambahan tepung cangkang telur pada pengolahan cookies dengan 3 perlakuan yaitu masing- masing 5\%, 10\%, $15 \%$ dan karakteristik terbaik yang didapat ialah pada penambahan $15 \%$ tepung cangkang telur.

Salah satu produk yang juga dapat diolah dari tepung cangkang telur adalah mie basah karena pada saat sekarang ini mie merupakan makanan yang sangat digemari banyak orang. Tak hanya orang dewasa bahkan anak-anak hingga balita pun sering mengkonsumsi mie, tak jarang juga masyarakat Indonesia menjadikan mie sebagai makanan pokok untuk anak meraka. Pada umumnya mie yang ada pada saat ini tidak memiliki kandungan yang cukup baik untuk memenuhi kebutuhan tubuh anak-anak. Bahkan kandungan gizinya pun sangat minim untuk dijadikan sebagai makanan pokok anak-anak dalam masa pertumbuhan.

Pada penelitian (Khasanah, 2016) percobaan dirancang dengan variasi penambahan tepung cangkang rajungan 
pada pembuatan mie basah sebesar $0 \%$ (control), 10\%, dan 20\%. Hasil penelitian menunjukkan bahwa perlakuan terbaik ialah pada penambahan tepung cangkang rajungan sebanyak $20 \%$ serta formulasi tepung cangkang rajungan dan tepung terigu pada mie basah yang dihasilkan berpengaruh terhadap kadar air, kadar abu, protein, dan juga terhadap kadar kalsium.

Dalam masa pertumbuhan anakanak sangat memerlukan makanan yang memiliki kandungan gizi yang baik untuk mendukung pertumbuhannya, salah satunya adalah kalsium untuk mendukung pertumbuhan tulang dan gigi anak-anak serta mencegah terjadinya osteoporosis diusia lanjut.

Penambahan tepung cangkang telur ayam ras dalam proses pembuatan mie dapat dijadikan sebagai alternatif pembuatan mie yang sehat, memiliki kalsium yang tinggi dan baik dikonsumsi oleh orang dewasa, usia lanjut, anakanak hingga balita dalam proses pertumbuhan. Tak hanya itu ibu hamil serta menyusui sangat baik untuk mengkonsumsi makanan yang kaya gizi dan kalsium yang tinggi.

Dari penelitian (Rahmawati, 2014) yang menambah tepung cangkang telur pada pengolahan cookies dengan perlakuan terbaik penambahan tepung cangkang telur $15 \%$ dapat berpengaruh terhadap karakteristik cookies yang dihasilkan. Namun belum ada penelitian yang menambahkan tepung cangkang telur pada pembuatan mie basah, serta belum diketahui persentase penambahan tepung cangkang telur untuk menghasilkan karakteristik yang baik pada mie basah.

Berdasarkan permasalahan tersebut maka penulis tertarik untuk melakukan penelitian yang berjudul "Pengaruh Penambahan Tepung Cangkang Telur
Terhadap Karakteristik Mie Basah yang Dihasilkan".

\section{Tujuan Penelitian}

Tujuan dari penelitian ini adalah untuk mengetahui persentase tepung cangkang telur yang tepat pada pengolahan mie basah terhadap karakteristik mie basah yang dihasilkan.

\section{Manfaat Penelitian}

Manfaat dari penelitian adalah sebagai berikut :

1. Dapat menjadi salah satu alternatif untuk pemanfaatkan cangkang telur menjadi bahan yang bisa berguna didalam pengolahan produk pangan.

2. Dapat dijadikan informasi pengolahan mie basah dengan menggunakan cangkang telur sebagai makanan yang berkalsium tinggi.

\section{METODOLOGI PENELITIAN}

\section{Bahan}

Bahan utama yang digunakan pada penalitian ini adalah cangkang telur dalam keadaan bersih yang telah diolah menjadi tepung. Asal serat yang digunakan adalah tepung terigu. Bahan tambahan yang digunakan adalah telur ayam, air bersih, pengenyal mie (natrium karbonat dan kalium karbonat), garam, dan minyak.

Bahan yang digunakan untuk analisis kimia adalah bahan pengering (fosfor pentoksida kering, kalsium klorida dan butiran halus silika gel), akuades, amonium oksalat jenuh, indikator merah muda, alkohol 95\%, asam asetat encer, amonium hidroksida encer dan $\mathrm{KmnO}_{4}$ 0,1 $\mathrm{N}$.

\section{Alat \\ Peralatan yang digunakan adalah sikat gigi, oven, termometer, timbangan analitik, sendok, tirisan, pisau, wadah pengadonan, ayakan, penggiling mie,}


nampan, sarung tangan plastik, gelas, mangkok, baskom, kompor, dan panci.

Alat yang digunakan untuk analisis kimia adalah oven, cawan dengan penutupnya, desikator, penjepit, timbangan analitik, pipet 20-100 ml, gelas piala 250 , kertas saring whatman no.42, cawan pengabuan (terbuat dari platina, nikei, atau silika dan lengkap dengan tutupnya), tanur pengabuan dan penjepit cawan.

\section{Metode Penelitian}

Perlakuan penelitian pada mie basah dengan penambahan tepung cangkang telur menggunakan perbandingan tepung terigu dengan tepung cangkang telur. Dengan bahan telah ditentukan yaitu 250 gram tepung terigu setiap perlakuan. Adapun perlakuan tersebut adalah:

$\mathrm{P} 1=$ Tepung cangkang telur 7,5\% / bb

$\mathrm{P} 2=$ Tepung cangkang telur $15 \% / \mathrm{bb}$

P3 $=$ Tepung cangkang telur $22,5 \% / \mathrm{bb}$

P4 = Tepung cangkang telur $30 \% / b b$

Rancangan prcobaan yang dilakukan pada penelitian ini adalah rancangan acak lengkap dengan 4 perlakuan dan 3 kali ulangan sehingga diperoleh pola perlakuan $4 \times 3$ dengan 12 unit percobaan, dengan model linear sebagai berikut :

Dimana:

$$
Y_{i j}=\mu+p i+E i j
$$

$\mathrm{Y}_{\mathrm{ij}}=$ hasil pengamatan pada mie basah tepung cangkang telur yang mendapat perlakuan ke-i danulangan ke-j

$\mu=$ rata-rata populasi atau nilai tengah umum

pi $=$ pengaruh perlakuan ke-i

Eij = pengaruh sisa perlakuan ke-i dan ulangan ke-j
Dari hasil analisa data dilakukan dengan analisa statistik apabila $F_{\text {hitung }}>F_{\text {tabel }}$ (beda nyata) maka dilanjutkan dengan uji BNT (Beda Nyata Terkecil) pada taraf nyata $5 \%$.

\section{Pelaksanaan Penelitian}

Proses pelaksanaan penelitian yang mengolah mie basah dengan penambahan tepung cangkang telur untuk mengetahui pengaruh terhadap karakteristik mie basah yang dihasilkan terdiri dari beberapa tahapan yaitu, pencucian cangkang telur, perebusan cangkang telur, pengeringan cangkang telur, pengecilan ukuran cangkang telur, penggilingan cangkang telur, pengayakan tepung cangkang, pencampuran, pengulenan, pebentukan lembaran, pencetakan, perebusan dan pendinginan.

\section{HASIL DAN PEMBAHASAN}

\section{Kadar Kalsium}

Kalsium merupakan mineral yang penting untuk manusia, 99\% kalsium didalam tubuh manusia terdapat ditulang dan sebanyak $1 \%$ kalsium terdapat didalam cairan tubuh seperti serum darah, disel-sel tubuh, dalam cairan ekstra seluler dan intraseluler. Kalsium merupakan mineral yang paling banyak terdapat dalam tubuh manusia, yaitu sekitar 1,5-2\% berat badan (Shita 2015).

Analisa kalsium pada mie basah ini dilakukan untuk mengetahui pengaruh penambahan tepung cangkang telur terhadap mie basah yang dihasilkan, mengetahui persentase kalsium disetiap perlakuan. Pada analisa ini menunjukkan tidak adanya berbeda nyata pada setiap perlakuan, karna $\mathrm{F}_{\text {hitung }}$ $<\mathrm{F}_{\text {tabel. }}$. Hasil analisa dapat dilihat pada Tabel 1 . 
Tabel 1. Rata-rata Analisa Kadar Kalsium terhadap Mie Basah

\begin{tabular}{|l|c|}
\hline \multicolumn{1}{|c|}{ Perlakuan } & Rata-rata (\%) \\
\hline $\mathrm{B}=$ penambahan tepung cangkang telur 15\% / berat bahan & $0,49 \mathrm{a}$ \\
\hline $\mathrm{D}=$ penambahan tepung cangkang telur 30\% / berat bahan & $0,43 \mathrm{ab}$ \\
\hline $\mathrm{A}=$ penambahan tepung cangkang telur 7,5\% / berat bahan & $0,32 \mathrm{ab}$ \\
\hline $\mathrm{C}=$ penambahan tepung cangkang telur 22,5\% / berat bahan & $0.26 \mathrm{~b}$ \\
\hline
\end{tabular}

Keterangan: angka-angka pada jalur yang sama diikuti oleh huruf kecil yang sama menunjukkan berbeda tidak nyata menurut Uji Beda Nyata Terkecil pada taraf 5\%

Dari tabel 1 dapat diketahui hasil analisa kasium berkisar antara 0,26\% $0,49 \%$, dengan perlakuan terbaik ialah pada perlakuan $B$ dengan persentase penambahan tepung cangkang telur sebanyak $15 \%$ per berat tepung terigu dimana persetase kalsum tertinggi yaitu $0,49 \%$. Sedangkan perlakuan yang memiliki persentase kalsium terendah ialah pada perlakuan $\mathrm{C}$ dengan persentase penambahan tepung cangkang telur sebanyak $22,5 \%$.

Perlakuan A berbeda tidak nyata dengan perlakuan $\mathrm{B}, \mathrm{C}$ dan $\mathrm{D}$, perlakuan $B$ berbeda tidak nyata dengan perlakuan A dan $\mathrm{D}$ dan berbeda nyata dengan perlakuan $\mathrm{C}$, perlakuan $\mathrm{C}$ berbeda tidak nyata dengan perlakuan $\mathrm{A}$ dan $\mathrm{D}$ dan berbeda nyata dengan perlakuan B serta perlakuan $\mathrm{D}$ berbeda tidak nyata dengan perlakuan A, B dan C.

Dari hasil analisa kalsium ini dapat diketahui bahwa dengan persentase penambahan tepung cangkang telur yang banyak belum tentu persentase kalsium pada mie basah lebih banyak juga. Karena pada proses pembuatan mie basah ini kulit telur terebih dahulu direbus, lalu setelah diadon dan membentuk mie mentah kembali dilakukan perebusan. Sehingga kalsiumnya terlepas pada saat dilakukan perebusan. Pemanasan tersebut diduga berpengaruh pada proses adsorpi kalsium dan terlepas (Setyopratiwi 2007).

Dengan penambahan tepung cangkang telur pada mie basah berpengaruh terhadap persentase kalsium yang terkandung didalam mie basah tersebut, dikarena pada dasarnya mie basah tidak mengandung kalsium, sehingga dengan penambahan tepung cangkang telur akan membuat mie basah memiliki kandungan kalsium untuk memenuhi kebutuhan kalsium dalam tubuh.

\section{Kadar Air}

Analisa kadar air pada mie basah dilakukan untuk mengetahui jumlah persentase kadar air pada setiap perlakuan, serta dapat mengetahui pada perlakuan mana yang memiliki kandungan air terendah dan tertinggi pada penelitian mie basah ini dan juga dapat dapat mengetahui dengan penambahan tepung cangkang telur dapat berpengaruh terhadap kadar air pada mie basah tersebut. Dari hasil analisa kadar air ini diketahui bahwa $\mathrm{F}_{\text {hitung }}>\mathrm{F}_{\text {tabel }}$, sehingga harus dilakukan uji lanjut BNT. Hasil rata-rata analisa kadar air dapat dilihat pada Tabel 2. 
Tabel 2. Rata-rata Analisa Kadar Air terhadap Mie Basah

\begin{tabular}{|l|c|}
\hline \multicolumn{1}{|c|}{ Perlakuan } & Rata-rata (\%) \\
\hline $\mathrm{A}=$ penambahan tepung cangkang telur 7,5\% / berat bahan & $19.333 \mathrm{a}$ \\
\hline $\mathrm{B}=$ penambahan tepung cangkang telur $15 \%$ / berat bahan & $18.000 \mathrm{ab}$ \\
\hline $\mathrm{C}=$ penambahan tepung cangkang telur $22,5 \%$ / berat bahan & $17.333 \mathrm{ab}$ \\
\hline $\mathrm{D}=$ penambahan tepung cangkang telur 30\% / berat bahan & $14.000 \mathrm{~b}$ \\
\hline
\end{tabular}

Keterangan: angka-angka pada jalur yang sama diikuti oleh huruf kecil yang sama menunjukkan berbeda tidak nyata menurut Uji Beda Nyata Terkecil pada taraf 5\%

Pada Tabel 2 ini menunjukkan bahwa angka rata-rata hasil analisa kadar air pada mie basah berkisar antara $14,000 \%-19.333 \%$, yang mana angka terkecil menunjukan kadar air terendah yaitu pada perlakuan D (14.000 \%) dengan persentase penambahan tepung cangkang telur sebanyak $30 \%$ per berat tepung terigu. Sedangkan angka tertinggi yang menunjukkan kadar air tertinggi yaitu pada perlakuan A $(19.333 \%)$ dengan persentase penambahan tepung cangkang telur sebanyak $7,5 \%$ per berat tepung terigu.

Perlakuan A berbeda tidak nyata dengan perlakuan $\mathrm{B}$ dan $\mathrm{C}$ dan berbeda nyata dengan perlakuan $\mathrm{D}$, perlakuan $\mathrm{B}$ berbeda tidak nyata dengan perlakuan A, $\mathrm{C}$ dan $\mathrm{D}$, perlakuan $\mathrm{C}$ berbeda tidak nyata dengan perlakuan $\mathrm{A}, \mathrm{B}$ dan $\mathrm{D}$, serta perlakuan $\mathrm{D}$ berbeda tidak nyata dengan perlakuan $\mathrm{B}$ dan $\mathrm{C}$ dan berdeda nyata dengan perlakuan $\mathrm{A}$.

Dari data tersebut menunjukkan bahwa semakin besar persentase penambahan tepung cangkang telur maka semakin rendah kandungan kadar air di dalam mie basah tersebut dan sebaliknya semakin kecil persentase penambahan tepung cangkang telur maka semakin tinggi kandungan kadar air didalam mie tersebut. itu dikarenakan tepung cangkang telur tidak menyerap air sehingga pada perlakuan yang menggunakan tepung cangkang telur yang banyak tidak mengandung air yang banyak.

\section{Kadar Abu}

Analisa kadar abu pada mie basah dilakukan untuk mengetahui kadar abu yang terkandug didalam mie basah serta persentase penambahan kadar abu pada setiap perlakuan. Dari hasil analisa kadar abuu pada mie basah didapat bahwa $F_{\text {hitung }}>F_{\text {tabel, }}$, sehingga perlu dilakukan uji lanjut BNT taraf 5\%. Hasil rata- rata analisa kadar abu dapat dilihat pada Tabel 3.

Tabel 3. Rata-rata Analisa Kadar Abu terhadap Mie Basah

\begin{tabular}{|l|c|}
\hline \multicolumn{1}{|c|}{ Perlakuan } & Rata-rata (\%) \\
\hline $\mathrm{D}=$ penambahan tepung cangkang telur 30\% / berat bahan & $9.00 \mathrm{a}$ \\
\hline $\mathrm{C}=$ penambahan tepung cangkang telur 22,5\% / berat bahan & $4.33 \mathrm{ab}$ \\
\hline $\mathrm{B}=$ penambahan tepung cangkang telur $15 \%$ / berat bahan & $4.00 \mathrm{ab}$ \\
\hline $\mathrm{A}=$ penambahan tepung cangkang telur 7,5\% / berat bahan & $1.33 \mathrm{~b}$ \\
\hline
\end{tabular}

Keterangan: angka-angka pada jalur yang sama diikuti oleh huruf kecil yang sama menunjukkan berbeda tidak nyata menurut Uji Beda Nyata Terkecil pada taraf 5\% 
Pada Tabel 3 menunjukkan bahwa rata-rata hasil analisa kadar abu pada mie basah berkisar antara $1.33 \%$ $9.00 \%$, yang mana angka terkecil menunjukkan kadar abu terendah yaitu pada perlakuan A (1.33\%) dengan persentase penambahan tepung cangkang telur sebanyak $7,5 \%$ per berat tepung terigu dan angka terbesar menunjukkan kadar abu tertinggi pada mie basah pada perlakuan D $(9.00 \%)$ dengan persentase penambahan tepung cangkang telur sebanyak $30 \%$ per berat tepung terigu.

Perlakuan A berbeda tidak nyata dengan perlakuan $\mathrm{B}$ dan $\mathrm{C}$ dan berbeda nyata dengan perlakuan $\mathrm{D}$, perlakuan $\mathrm{B}$ berbeda tidak nyata dengan perlakuan A, $\mathrm{C}$ dan $\mathrm{D}$, perlakuan $\mathrm{C}$ berbeda tidak nyata dengan perlakuan $\mathrm{A}, \mathrm{B}$ dan $\mathrm{D}$, serta perlakuan $\mathrm{D}$ berbeda tidak nyata dengan perlakuan $\mathrm{B}$ dan $\mathrm{C}$ dan berbeda nyata dengan perlakuan $\mathrm{A}$.

Dari data tersebut menunjukkan bahwa semakin besar persentase penambahan tepung cangkang telur maka akan semakin besar pula kandungan kadar abu pada mie basah ini, sebaliknya semakin sedikit persentase penambahan tepung cangkang telur maka akan semakin rendah kandungan kadar abu didalamnya hal tersebut dikarenakan tepung cangkang telur memiliki kandungan kadar au yang tinggi. Hal itu sependapat dengan (Wijaya 1977 dalam khasanah 2016), mineral yang digolongkan sebagai zat organik disebut unsur abu dalam bahan pangan, karena jika pangan dipanaskan unsur organik akan menghilang dan bahan organik yang termasuk abu yang tersisa terdiri dari unsur mineral, sehingga kadar abu meningkat seiring menigkatnya konsentrasi penambahan tepung cangkang rajungan.

Dari hasil analisa ini maka diketahui perlakuan terbaik yaitu pada perlakuan A yang memiliki nilai ratarata kadar abu $1.33 \%$ dengan penambahan tepung cangkang telur sebanyak $7,5 \%$ per berat tepung terigu, pada perlakuan A yang memenuhi standar mutu mie basah dengan persentase kadar abu maksimum 3\%. Sedangkan pada perlakuan yang lain kandungan kadar abu melebihi batas maksimum standar mutu mie basah (SNI 2046-90). Tingginya kadar abu pada produk ini disebabkan karena kadar abupada tepung cangkang telur cukup tinggi, karena pada cangkang telur terdapat zat kapur $\left(\mathrm{CaCO}_{3}\right)$ sebagai bahan utama penyusun cangkang telur (Rahmawati 2015).

\section{Uji Organoleptik}

Uji organoleptik merupakan cara penilaian terhadap mutu atau sifat suatu produk dengan menggunakan beberapa orang panelis, dimana uji organoleptik meliputi penilaian terhadap rasa, warna, aroma dan tekstur produk. Penilaian ini dilakukan untuk mengetahui bagaimana respon panelis terhadap masing-masing mie basah yang diujikan.

Berdasarkan data hasil uji organoleptik berikut disajikan nilai ratarata masing-masing perlakuan dalam Tabel 4 dan Gambar 1.

Tabel 4. Rata-rata uji organoleptik terhadap mie basah

\begin{tabular}{|c|c|c|c|c|}
\hline Pengujian & $\mathrm{A}(7,5 \%)$ & $\mathrm{B}(15 \%)$ & $\mathrm{C}(22,5 \%)$ & $\mathrm{D}(30 \%)$ \\
\hline Rasa & 3,7 & 4 & 3,8 & 3,7 \\
\hline Warna & 4,5 & 3,95 & 3,4 & 3,05 \\
\hline Aroma & 3,4 & 3,55 & 3,4 & 3,2 \\
\hline Tekstur & 3,55 & 3,5 & 3,35 & 3,25 \\
\hline
\end{tabular}



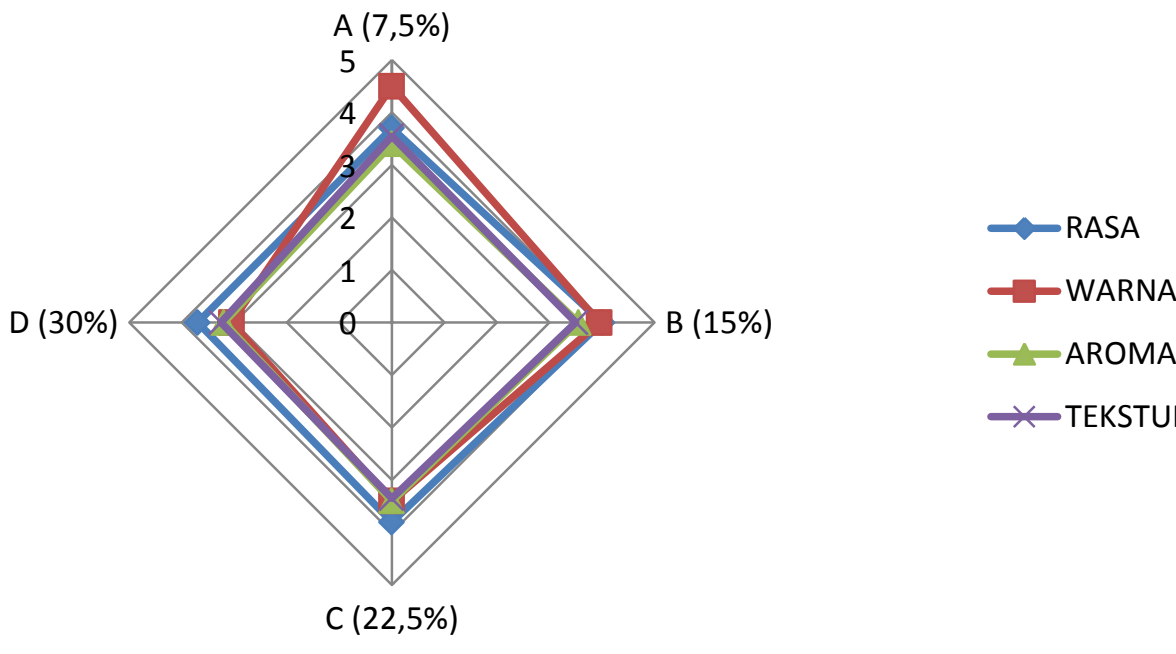

$\because$ AROMA

$\because$ TEKSTUR

Gambar 1. Radar Organoleptik

Dari tabel 4 dan gambar 1 menunjukan bahwa hasil uji organoleptik pada rasa berkisar antara $3,7-4$, yang mana rasa yang disukai oleh panelis adalah pada perlakuan B dengan skor 4 dan yang tidak disukai panelis adalah pada perlakuan A dan D dengan skor yang sama yaitu 3,7.

Hasil uji organoleptik pada warna berkisar antara 3,05 - 4,5, yang mana warna yang disukai oleh panelis adalah pada perlakuan A dengan skor 4,5 dan yang tidak disukai oleh panelis adalah pada perlakuan D dengan skor 3,05.

Hasil uji organoleptik pada aroma berkisar antara 3,2 - 3,55, yang mana aroma yang disukai oleh panelis adalah pada perlakuan B dengan skor 3,55 dan yang tidak disukai oleh panelis adalah pada perlakuan D dengan skor 3,2.

Hasil uji organoleptik pada terkstur berkisar antara 3,25 - 3,55, yang mana tekstur yang disukai oleh panelis adalah pada perlakuan A dengan skor 3,55 dan yang tidsk disukai oleh panelis adalah pada perlakuan D dengan skor 3,25.

\section{KESIMPULAN DAN SARAN}

\section{Kesimpulan}

Kesimpulan yang dapat diperoleh setelah melakukan penelitian ini ialah hasil terbaik pada mie basah yang dihasilkan yaitu perlakuan A dengan penambahan tepung cangkang telur sebanyak $7,5 \%$ per berat tepung terigu, yang mempunyai nilai rasa 3,7 , warna 4,5, aroma 3,4, tekstur 3,5, kandungan air 19,33\%, kandungan kalsium 0,32\% dan kandungan abu 1,3\%.

\section{Saran}

Penelitian ini hanya dibatasi pada pengamatana danya perubahan fisik pada mie basah dan kandungan kimiawi mie basah yang dihasilkan. Hal yang menarik apabila ada yang berminat untuk melanjutkan penelitian ini dengan pengamatan secara mikrobiologi terhadap mie basah yang telah ditambahkan tepung cangkang telur dan melakukan penelitian untuk menghasilkan tepung cangkang telur yang lebih halus agar tekstur pada mie basah lebih lembut pada saat dimakan 


\section{DAFTAR PUSTAKA}

Harahap AN. 2007. Pembuatan Mie Basah dengan Penambahan Wortel (DaucusCarota L). Skripsi TPHP Pertanian.Universitas Sumatera Utara.

Hardjasasmita P. Ikhtisar biokimia dasar. Jakarta: Balai Penerbit FKUI. 2006.

Ketaren, S. 2008. Minyak dan Lemak Pangan. Jakarta: Universitas Indonesia.

Khasanah S, Hartati I. 2016. Analisa Proksimat Mie Basah yang Difortifikasi dengan Tepung Cangkang Rajungan (Portumus Palagicus). Jurnal Inovasi Teknik Kimia. Fakultas Teknik Universitas Wahid Hasyim. Semarang.

Koswara S.2009. Teknologi Pengolahan Mie. eBook pangan.com.

Lesmana SN, Putut TI, Kusumawati N. 2008. Pengaruh Penambahan Kalsium Karbonat Sebagai FortifikanKalsium Terhadap Sifat Fisikokimia Dan Organoleptik Permen Jeli Susu. Jurnal Teknologi Pangan Dan Gizi. Surabaya: Fakultas Teknologi Pertanian Unika Widya Mandala Surabaya.

Lestari S, Susilawati NP. 2015. Jurnal Uji Organoleptik Mie Basah berbahan Dasar Tepung Talas Beneng (Xantoshoma Undipes) untuk Meningkatkan Nilai Tambah Bahan Pangan Lokal Banten. Balai Pengkajian Teknologi Pertanian. Banten.

Mairizon Y. 2013. Tepung Kerabang Telur. Bogor: IPB (diakses 21 November 2016).

Maulana A. 2013. Bahan- Bahan Untuk Membuat Mie. http:www.ariffox. blogspot.co.id/2013/05/bahan- bahan-untuk-membuat-mie.html. (diakses 10 November 2016).

Mitra, Wacana. Mie, Siapa Tak Kenal?.wacanamitra.blogspot.com. /2010/08/mie, siapa tak kenal? (diakses 12 November 2016).

Nurbaya S. 2014. Subtitusi Tepung Terigu dengan Campuran Tepung Jagung dan Tepung Ubi Jalar Dalam Pengolahan Mie Basah. Fakultas Pertanian Universitas Islam Indragiri. Indragiri Hilir.

Rahmawati AW, Nisa CF. 2014. Fortifikasi cangkang telur pada pembuatan cookies. Jurnal pangan dan agroindustri. Malang: FTP Universitas Brimawijaya.

Ramlan R. 2014. Pemanfaatan Limbah Cangkang Telur Yang Ramah Lingkungan.

http://www.slideshare.net/mobile/r andiramlan/pemanfaatan limbah cangkang telur (diakses 2 November 2016).

Retnaningsih C, Hartayani L. 2005. Aplikasi Tepung Iles-iles (Amorphopallus Konjac) Sebagai Pengganti Bahan Kimia Pengenyal Pada Mie Basah. Laporan penelitian. Semarang: Teknologi Pangan. Universitas Katolik Soegijapranata.

Rukmana A, Anggraeni D. 2008.Laboratorium ilmu nutrisi dan makanan ternak. Bogor: Fakultas Perternakan.

Santoso A. 2011. Serat Pangan (DIETARY FIBER) dan Manfaatny Bagi Kesehatan. jurnal. Klaten

Setyaningsih D, Apriantono A, Sari MP. 2010. Analisis Sensori Untuk Industri Pangan Dan Agro. Bogor: IPB PRESS.

Setyopratiwi A, Dkk. 2007. Pengaruh Pemanasan Terhadap Desorpsi Kalsium Oar I Blondo- Ca. 
Fakultas MIPA. Universitas Gadjah Mada. Yogyakarta.

Shita PDA, Sulistyani. 2015. Pengaruh Kalsium Terhadap Tumbuh Kembang Gigi Geligi Anak. Fakultas Kedokteran Gigi Universitas Jember.

Syah F. 2013. Resep Membuat Mie Basah Yang Enak Dan Kenyal. http://resep-masakan.info/resepmembuat-mie-basah-yang-enakdan-kenyal.html. (Diakses 28 September 2016)
Varcania RD. 2008. Penetapan Kadar Literatur Telur. Jakarta: Universitas Indonesia.

Wulansari Z, Badriyah C, Rahmawati L, Susana . 2013. Tugas Makalah Pengetahuan Hasil Ternak. Semarang: Fakultas Perternakan Dan Pertanian Universitas Diponerogo .http://www.zawusastory92.blogspot.co $\mathrm{m} / 2013 / 07 /$ cangkang telur sebagai sumber kalsium_3html? $\mathrm{m}=1$. (diakses 14 September 2016) 